\title{
A Study of Private Sector Secondary Schools in Relation to Corporate Social Responsibility in District Peshawar
}

\author{
TAZEEM AKHTAR WAZIR \\ Ph.D Scholar, Sarhad University of Science \& Information Technology Peshawar \\ YASIR KHAN KHALIL \\ Ph.D Scholar Qurtuba University Peshawar \\ HAMAYUN KHAN WAZIR \\ M.Phil Student Abdul Wali Khan University, Mardan
}

\begin{abstract}
Educational organizations in private sector require strong corporate strategies. In order to get success in the globally competitive environment they must adopt the strategy of Corporate Social Responsibility. This study analyzed corporate social responsibility and its impact on private sector secondary schools in district Peshawar, Khyber Pakhtunkhwa. For this purpose primary data were collected through five point Likert's scale. The questionnaire was fielded to private sector secondary school teachers in order to get data about the impact of corporate social responsibility on performance of secondary schools. The population of the study was 184 registered private sector secondary schools (140 boys and 44 girls) which included 900 teachers (who taught to class $10^{\text {th }}$ students during session 2017-18) in district Peshawar. A sample of 280 teachers (140 male and 140 female) in 70 private sector secondary schools (35 for boys and 35 for girls) were selected through equal allocation sampling formula. Mean, Standard Deviation and t-test were applied for analyzing the data. The Pearson's correlation $r$ was used to evaluate the variable effects. The result from the data indicated that all the four aspects of CSR have positive significant impact on the performance of secondary schools.
\end{abstract}

Keywords: Corporate Social Responsibility, Secondary Schools, District Peshawar, Khyber Pakhtunkhwa.

DOI: $10.7176 / \mathrm{JAAS} / 59-03$

Publication date: December $31^{\text {st }} 2019$

\section{Introduction}

Corporate Social Responsibility (CSR) has become an interesting topic for all educational organizations in the present age of competitive scenario. Especially educational institutions in the private sector have prioritized CSR approaches in their corporate goals. Thus they are focusing their attention on organizational success beyond classroom learning. By adopting such strategies, these organizations are striving for discovering opportunities to move their focus beyond classroom learning to their institutional performance.

Education sector is considered as the most socially rewarding and entitle institution for uplifting corporate social responsibility. Now a day, most of the private sector educational organizations are recognizing and accepting the pivotal role of corporate social responsibility and its contribution to society as obligatory and mandatory part of their business strategy. The strategies are helpful in specification and accomplishing of organizational goals and societal demands of diverse stakeholders. These strategies received much global significance and popularity especially in resolving various socio-economic problems of conservative minded nations (Asrar-ul-Haq, Kuchinke \& Iqbal, 2017).

Corporate social responsibility is defined as a mechanism that makes the organizations' responsible to societal interests while achieving their shareholders' profits (CORE, 2011). It refers to a volunteer action of business organizations taken for addressing their corporate interests and societal demands in the competitive business environment (BERR, 2009). It points out certain regulatory measures for creating a favorable environment for organizations in order to voluntarily fulfill their legal responsibilities for the benefits of society (European Commission Brussels, 2011). Organizations are adopting CSR approaches in their business activities for profit making and betterment of society (Yunus \& Weber, 2009).

Freeman (2011) stated that CSR is a type of self-regulatory system that makes the organizations responsible for their business dealing to all the stakeholders and society. It has shifted its traditional meaning from just obedience to the legislation towards socio-economic commitment for the development of society. McWilliams and Siegel (2001) defined it as a type of action taken for the welfare of society while achieving its organizational interests and is required by law. Pierce and Maddan (cited in Garavan and McGuire, 2010) documented that corporate social responsibility contributes in improving the life style of employees, their families, stakeholders and the whole community. Thus it has shifted its traditional meaning from just obedience to the legislation towards socio-economic commitment for the development of society.

Filho et al. (2010) reported that CSR refers to an ethical relationship and intelligibility between an 
organization and all its stakeholders. Porter and Kramer (2006) explored that it helps in formulating corporate goals and preserving cultural and environmental assets required for the upcoming generations of the society. It leads to the reduction of social problems and respects for diversity in society. Thus it recommends a way for organizations, in order to play active role in the welfare of society. It provides opportunities to the organizations for achieving positive image and reputation in the global competitive business environment.

Carroll (1979) described that CSR as a sum of four components i.e. economic, legal, ethical and discretional responsibility. He stated that economic responsibility refers to the organizations' concern for producing goods and services according to the demands of society. The legal responsibility is defined as a sense of commitments of organization with its operational rules and regulations. The ethical responsibility concern organizations to take care of societal interests beyond the law required. The discretionary responsibility refers to the organizations' approach of fulfilling extra responsibilities over and above the expectations of society.

This study focuses on the effect of Corporate Social Responsibility practices on the performance of private sector secondary schools of district Peshawar, Khyber Pakhtunkhwa. These strategies are means for improving and maintaining organizational reputation and producing its positive impact on society. Institutions, especially private one are needed to take into account two main aspects for their sustainable development. First one is the quality of management system. It refers to the improvement of organizational image through adoption of CSR. Second one is the nature and quality of such strategies that have positive impact on all the stakeholders of society.

\section{Theoretical Framework}

Carroll's (1979) four-dimensional model has been tested and admitted by researchers as a best description of Corporate Social Responsibility. He stated that these four components i.e. Economic, Legal, Ethical and Discretionary responsibility facilitate the appropriate analysis of different actions and performance of an organization. The four categories of CSR are helping organizations in identifying specific return of benefits to them. This study followed Carroll's model of corporate social responsibility for investigating the effect of CSR strategies on the performance of private sector secondary schools of district Peshawar, Pakhtunkhwa.

\section{Literature Review}

The concept of corporate social responsibility (CSR) got its origin in 1950 and USA was its mother country but it was well established in early 1970s. At this duration, US were confronted with many social problems such unemployment, poverty, environmental pollution and a big fall in the prices of dollar. Corporate Social Responsibility got significant value in diverse groups striving for revolution in the businesses. With the advent of 1980 s to 2000 time duration, organizations seriously felt the utmost need of recognizing and accepting social responsibility. CSR mainly concerns for the creation of money profits for the welfare of all the stakeholders consisting of shareholders, employees, customers, environment and society (Praveena and Vijaya, 2015).

In the new era of globalization and competition among educational organizations, many private sector educational organizations are willing for adaption of business-minded approach for their survival in the competitive education industry (Gumport 2000, Goia and Thomas 1996). By adopting business-minded approach, some organizations are recognizing the influential rule of Corporate Social Responsibility strategies in their corporate identity, image, advantage and brand reputation (Serap Atakan and Eker 2007, Stensaker 2007, Porter and Kramer 2006, Melewar and Akel 2005). The basic agenda of an organization is based on three main qualities i.e. identity, image and reputation and its distinctive attributes are guided by the CSR strategies (Mohammad et al. 2007).

Private sector educational organizations are willingly engaging with corporate social responsibility strategies for taking competitive advantage. Branco and Rodrigues (2006) explained that private sector organizations are adopting corporate social responsibility for gaining benefits in the competitive business environment. Hart (1995) documented that mostly organizations are following CSR strategies for generating a resource for their competitive advantage.

Dahlsrud (2008) summarized CSR in five organizational dimensions i.e. stakeholders, voluntariness, environmental, social and economics needed for the improvement of organizational practices. The Maignan and Ferrell (2000) categorized CSR in these four components such as economic, legal, ethical and social obligatory responsibilities of organizations towards their stakeholders. Galbreath (2010) stated that economic responsibility means the formulation of such economic strategies which are helpful in earning profits and covering expenditure. Legal responsibility refers to pursuing legal rules and regulations for fulfilling corporate economic mission according to a legal agenda. Ethical responsibility denotes to include moral rules in the strategies of organizations which are valued by society. While discretionary responsibility means adoption of such business activities which are not obligatory but valued and expected as a sign of motivation by stakeholders. 


\section{Need of the Study}

The concept of corporate social responsibility has been used in many business organizations and it has gained a significant social and economic importance in the past few decades in the global scenario. But unfortunately no research explaining relationship between corporate social responsibility and private sector educational organizations' performance is available in Pakistan. This is the first research of its type which focuses on investigating the relationship between corporate social responsibility and private sector high schools' performance in Pakistan.

\section{Objectives of the Study}

Following were objectives of the study:

1. To investigate the use of corporate social responsibility approaches in private sector secondary schools of district Peshawar.

2. To find out the relationship between corporate social responsibility and performance of private sector secondary schools of district Peshawar.

3. To compare male and female teachers' perceptions regarding advantages of corporate social responsibility practices for private sector secondary schools of district Peshawar.

4. To make recommendations for adoption of corporate social responsibility approaches in the network of private sector secondary schools.

\section{Hypotheses of the Study}

This study was guided by the following null hypotheses:

H01: There is no significant relationship between the four components of corporate social responsibility and performance of private sector secondary schools of district Peshawar.

H02: There is no significant difference between male and female teachers' perceptions regarding advantages of corporate social responsibility practices for employees and students of private sector secondary schools of district Peshawar.

\section{Methodology}

This study used quantitative research practice and descriptive design. The purpose of the study was to investigate corporate social responsibility in relation to private sector secondary schools of District Peshawar, Khyber Pakhtunkhwa.

\section{Population of the Study}

All the 900 teachers ( 710 male and 190 female teachers who taught to class $10^{\text {th }}$ students during session 2017-18) in 184 private sector secondary schools (140 boys and 44 girls) of district Peshawar constituted population of the study.

\section{Sample of the Study}

A sample of 300 teachers ( $20 \%$ of population) from 60 private sector secondary schools was selected through equal allocation sampling formula. The sample size was justified on the basis of rule of thumb of Gay \& Airasian (2003).

Validity and Reliability of the Questionnaire

A Questionnaire based on Carroll (1979) model of four components i.e. economic, legal, ethical and discretional responsibility was used for measuring views of employees regarding use and advantages of CSR practices in private sector secondary schools of Peshawar.

\section{Procedure of Data Collection}

The researcher obtained a list of all registered private sector secondary schools of district Peshawar from the Board of Intermediate \& Secondary Education. The Principals of such schools helped the researcher by providing the class timetable of the teachers. With the permission of the honorable Principals, the researcher randomly fielded 280 questionnaires to the selected teachers. The performance of private sector secondary schools was measured by the percentage of the selected schools class 10th students' annual examination result of 2018 (Akhtar et al. 2016).

\section{Analysis and Interpretation of Data}

The collected data were analyzed on the basis of the following five point Likert scale as; Strongly Disagree 1, Disagree 2, Undecided 3, Agree 4, and Strongly Agree 5. Software SPSS version-20 was used for the analysis of data. Frequencies, Percentages, Mean, Standard Deviation, t-test and Pearson's Correlation r were used. 
Results and Analysis

Table 1: Employees views regarding the use of Corporate Social Responsibility in Schools

\begin{tabular}{|l|l|l|l|l|l|l|l|l|}
\hline $\begin{array}{l}\text { S. } \\
\text { No }\end{array}$ & Statement & & SDA & DA & U & A & SA & Total \\
\hline $\mathbf{1}$ & \multirow{2}{*}{ Economic responsibility } & Freq & 13 & 19 & 19 & 36 & 193 & 280 \\
\cline { 3 - 9 } & & $\% \mathrm{ag}$ & 4 & 7 & 7 & 13 & 69 & 100 \\
\hline $\mathbf{2}$ & \multirow{2}{*}{ Legal Responsibility } & Freq & 3 & 26 & 3 & 68 & 180 & 280 \\
\cline { 3 - 9 } & & $\% \mathrm{ag}$ & 1 & 9 & 1 & 25 & 64 & 100 \\
\hline $\mathbf{3}$ & \multirow{2}{*}{ Ethical Responsibility } & Freq & 5 & 40 & 1 & 142 & 92 & 280 \\
\cline { 3 - 10 } & & $\% \mathrm{ag}$ & 2 & 13 & 1 & 51 & 33 & 100 \\
\hline $\mathbf{4}$ & \multirow{2}{*}{ Discretionary Responsibility } & Freq & 10 & 159 & 7 & 85 & 19 & 280 \\
\cline { 3 - 9 } & & $\% \mathrm{ag}$ & 3.6 & 57 & 2.5 & 30 & 6.8 & 100 \\
\hline
\end{tabular}

Table 1 shows the views of the private school teachers on the use of corporate social responsibility practices in their schools. Statement 1 indicates that $69 \%$ of the employees are saying that Economic Strategies of CSR are given high importance in their schools. Statement 2 denotes that $64 \%$ of the employees are admitting that Legal Strategies of CSR are used with high significance in their institutions. Statement 3 signifies that $51 \%$ employees are about the view that Ethical Responsibility of CSR is valued in their schools. Statement 4 indicates that $57 \%$ employees are disagreeing with the statement that Discretionary Responsibility admired in their schools.

Table 2: Correlation between Corporate Social Responsibility and Private Sector Educational Organizations' Performance

\begin{tabular}{|l|l|c|}
\hline S.No & Statements & C-Coefficient \\
\hline $\mathbf{1}$ & Economic Responsibility and Organization Performance & 0.97 \\
\hline $\mathbf{2}$ & Legal Responsibility and Organization Performance & 0.92 \\
\hline $\mathbf{3}$ & Ethical Responsibility and Organization Performance & 0.55 \\
\hline $\mathbf{4}$ & Discretionary Responsibility and Organization Performance & 0.38 \\
\hline
\end{tabular}

*Correlation between the two variables was analyzed through Mangal (2004) guide for interpretation of coefficient correlation.

Table 2 shows correlation between Corporate Social Responsibility and private sector secondary schools' performance. Statement 1 shows that there exists positive very high correlation between Economic Responsibility of CSR and performance of secondary schools in private sector with correlation coefficient value 0.97 , Hence it leads to the rejection of null hypothesis. Statement 2 signifies that there exists very high positive correlation between Legal Responsibility of CSR and schools' performance with correlation coefficient value 0.92 and it leads to the rejection of null hypothesis. Statement 3 indicates that there found moderate positive correlation between Ethical Responsibility of CSR and private sector schools' performance with correlation coefficient value 0.55 . The hypothesis of no correlation between the two categories is rejected by the results. Statement 4 denotes that there seen low positive correlation between Discretionary Responsibility of CSR and educational institutions performance with correlation coefficient value 0.38 . Thus it leads to the rejection of null hypothesis.

Table 3: Comparison between Male and Female Teachers' views regarding the use of Corporate Social Responsibility in Schools

\begin{tabular}{|c|c|c|c|c|c|c|}
\hline S.No & Statements & Category & Mean & S.D & t- value & $\mathbf{P}$ \\
\hline \multirow{2}{*}{1} & \multirow[t]{2}{*}{ Economic Responsibility } & Male & 4.32 & 1.25 & \multirow{2}{*}{0.98} & \multirow{2}{*}{0.31} \\
\hline & & Female & 4.16 & 1.49 & & \\
\hline \multirow{2}{*}{2} & \multirow[t]{2}{*}{ Legal Responsibility } & Male & 4.14 & 1.45 & \multirow{2}{*}{0.40} & \multirow{2}{*}{0.69} \\
\hline & & Female & 4.09 & 1.56 & & \\
\hline \multirow{2}{*}{3} & \multirow[t]{2}{*}{ Ethical Responsibility } & Male & 4.06 & 1.49 & \multirow{2}{*}{0.21} & \multirow{2}{*}{0.84} \\
\hline & & Female & 4.09 & 1.43 & & \\
\hline \multirow{2}{*}{4} & \multirow[t]{2}{*}{ Discretionary Responsibility } & Male & 3.54 & 1.85 & \multirow{2}{*}{1.03} & \multirow{2}{*}{0.30} \\
\hline & & Female & 3.76 & 1.76 & & \\
\hline
\end{tabular}

Table 3 indicates the mean standard deviation t- value and p- value of both the categories. Statement 1 shows that mean of male teachers is 4.32 and standard deviation 1.25. While female teachers have Mean 4.16 and Standard Deviation $1.49, \mathrm{t}$-value is 0.98 and $\mathrm{p}$-value is 0.31 . Since p-value is greater than 0.05 , so the null hypothesis of no significant difference between male and female regarding advantage of Economic Responsibility of CSR for schools cannot be rejected. Statement 2 indicates Mean of male teachers is 4.14 and Standard Deviation 1.45, while Mean of female teachers is 4.09 and Standard Deviation 1.56 with t-value 0.40 and $p$-value is 0.69 , as $\mathrm{p}$ value is greater than 0.05 , so there is no significant difference between male and female regarding Legal Responsibility of CSR. Thus the null hypothesis of cannot be rejected. Statement 3 denotes male 
teachers have Mean 4.06 and Standard Deviation 1.49. While female teachers have Mean 4.09 and Standard Deviation 1.43 , since p-value is greater than 0.05 , so there is no significant difference between male and female regarding usefulness of Ethical Responsibility of CSR for institutions and the null hypothesis can't be rejected." Statement 4 shows Mean of male teachers is 3.54 and Standard Deviation 1.85, while Mean of female teachers is 3.76 and Standard Deviation 1.76 with t-value 1.03 and p-value is 0.30 . Since p value is greater than 0.05 , so the null hypothesis of no significant difference between male and female regarding importance of Discretionary Responsibility of CSR for schools cannot be rejected. It indicates that there exists no significant difference between male and female employees' views regarding advantages of Corporate Social Responsibility (CSR) approaches for their schools. Both male and female employees have probably same views on the usefulness of Corporate Social Responsibility practices for their institutions.

\section{Findings}

The following were the findings of the study:

Table 1 shows the views of the private school teachers' views on the use of Corporate Social Responsibility Strategies in their schools. Statement 1 shows that employees are Strongly Agree that Economic Responsibility of CSR are followed in their schools. Statement 2 indicates that the employees Strongly Agree as Legal Strategies of CSR are used in their school. Statement 3 illustrates that employees are Agree about the statement of the use of Ethical Responsibility of CSR in their schools. Statement 4 denotes that employees are Disagree with the wording that Discretionary Strategy is used in their schools.

Table 2 signifies correlation between the components of Corporate Social Responsibility and private sector secondary schools' performance. Statement 1 shows that there exists positive very high correlation between Economic Responsibility and institutional Performance. Statement 2 demonstrates that there shown positive very high correlation between Legal Responsibility and institutional performance. Statement 3 depicts that there found moderate positive correlation between Ethical Responsibility and private sector educational organizations' performance. Statement 4 displays that there seen low positive correlation between Discretionary Responsibility and performance of schools.

Table 3 depicts the Mean standard deviation t- value and p-value of both male and female views on all the four components of Corporate Social Responsibility such as Economic, Legal, Ethical and Discretional responsibilities. It indicates that there is no significant difference between male and female employees' views regarding the use of Economic, Legal, Ethical and Discretionary Strategies of Corporate Social Responsibility in their schools. Thus the null hypothesis of no significant difference between male and female views on the use of Corporate Social Responsibility strategies in their schools cannot be rejected. Probably both the gender has same views regarding advantages of CSR for their schools.

\section{Conclusions}

The following conclusions were made:

Table 1 indicates the views of teachers in the private sector educational organizations regarding use of corporate social responsibility practices in their schools. It is concluded from the findings of the study that the two statements Economic Strategies and Legal Strategies of CSR are highly valued and followed in their schools. The third Statement Ethical Strategies of CSR is also positively valued and obeyed in their schools. The fourth Discretionary Strategies are used in their schools but with a very little importance.

Table 2 illustrates correlation between the components of Corporate Social Responsibility and Private Sector Educational Organizations' Performance. It is concluded that there exists positive very high correlation between Economic Responsibility and Legal Responsibility of CSR and performance of schools, while there exists moderate positive correlation between Ethical Responsibility of CSR and Private Sector institutional performance. On the other hand, there exists low positive correlation between "Discretionary Responsibility of CSR and schools' performance.

Table 3 shows that there is no significant difference between male and female employees' views on the use of Corporate Social Responsibility (CSR) strategies in their schools. Both male and female employees have probably same views on the use of Corporate Social Responsibility (CSR) strategies in their schools.

\section{Recommendations of the Study}

1. There appears due need that secondary school heads of private schools should make optimal use of the discretionary powers for solutions of problems.

2. These schools are required to organize community service program frequently in order to satisfy investors' expectations and society demands.

3. These institutions should engage in charitable activities by donating a certain share of their profits to charitable causes.

4. The schools should provide free school uniforms, notebooks and other stationary material to poor students. 
5. The schools should organize health care camps for students and poor reduction seminars in society.

\section{References}

Akhtar, T., Shah, R., Ghazi, S. R. \& Khalil, Y. K. (2016). Morale as Predictor of Secondary School Teachers' Performance: A Study of the Schools of Khyber Pakhtunkhwa. The dialogue, 11(4), 388-400.

Asrar-ul-Haq, M., Kuchinke, K. P. \& Iqbal, A. (2017). The relationship between corporate social responsibility, job satisfaction, and organizational commitment: Case of Pakistani higher education. Journal of Cleaner Production, 142, 2352-2363. https://doi.org/10.1016/j.jclepro.2016.11.04

Branco, M. C. \& Rodrigues, L. L. (2006). Corporate social responsibility and resource based perspectives. Journal of Business Ethics, 69(2), 111-132. https://ideas.repec.org > kap > jbuset > v69y2006i2p111-132

Business Enterprise \& Regulatory Reform (2009). Corporate responsibility report, London: HM Government.

Carroll, A. B. (1979). A Three Dimensional Model of Corporate Social Performance. Academy of Management Review, 4(4), 497-505.

CORE (2012). CORE Values: Why the UK Needs a Commission for Business, Human Rights and the Environment', The Corporate Responsibility Coalition. Available from http://corporateresponsibility.org/wp-content/uploads/2011/04/CORE values.pdf (Accessed 30 August, 2012).

Dahlsrud, A. (2008). How Corporate Social Responsibility is Defined: an Analysis of 37 Definitions. Published online in Wiley Inter Science, 1-13. www.interscience.wiley.com. DOI: 10.1002/csr.132.

European Commission Brussels (2011). Communication from the Commission to the European Parliament, the Council, the European Economic and Social Committee and the Committee of the Regions.

Freeman, I. \& Hasnaoui, A. (2011). The Meaning of Corporate Social Responsibility: the Vision of Four Nations. Journal of Business Ethics, 100, 419-443. http://dx.doi.org/10.1007/s10551-010-0688-6

Filho, S. J. M., Wanderley, L. S. O., Gomez, C. P. \& Farache, F. (2010). Strategic Corporate Social Responsibility Management for Competitive Advantage. 7 (3), 294-309. BAR-Brazil Administration Review On-line version ISSN 1807-7692.

http://dx.doi.org/10.1590/S1807-76922010000300006

Galbreath, J. (2010). How does Corporate Social Responsibility benefit Firms? Evidence from Australia. European Business Review, 22 (4), 411-431. doi.10.1108/09555341011056186.

Garavan, N. T. \& McGuire, D. (2010). Human Resource Development and Society: Human Resource Development's Role in Embedding Corporate Social Responsibility, Sustainability, and Ethics in Organizations. Advances in Developing Human Resources Sage Publications, 12 (5), 487507.doi.org/10.1177/1523422310394757.

Gay, L. R., \& Airasian, P. (2003) (2003). Educational Research London: Competencies for Analysis and applications ( $7^{\text {th }}$ Ed.). Upper Saddler River, NJ: Merrill Printice Hall.

Goia, D. A., \& Thomas, J. B. (1996). Institutional identity, image, and issue interpretation: Sense making during strategic change in academia. Administrative Science Quarterly, 41(3), 370-403. http://dx.doi.org/10.2307/2393936

Gumport, P. J. (2000). Academic Restructuring: Organizational Change and Institutional Imperatives. Higher Education 39, 67-91.

http://citeseerx.ist.psu.edu/viewdoc/download?doi=10.1.1.536.7788

Hart, S. L. (1995). A Natural-Resource-Based View of the Firm. Academic Management Review, 20 (4), 9861014. doi.org/10.5465/AMR.1995.9512280033

Maignan, I. \& Ferrell, O. (2000). Measuring Corporate Citizenship in two Countries; The Case of the United States and France. Journal of Business Ethics, 23 (3), 283-297. doi.org/10.1023/A:1006262325211.

Mangal, S. K.(2004), An Introduction to Psychology. Delhi: Sterling Publishers Private Limited.

McWilliams, A. \& Siegel, D. (2001). Corporate Social Responsibility: A Theory of the Firm Perspective. Academy of Management Review, 26(1), 117-127. Doi.org/10.5465/AMR.2001.4011987.

Melewar, T. C. \& Akel, S. (2005). The Role of Corporate Identity in the Higher Education Sector A Case Study." Corporate Communications: An International Journal, 10 (1), 41-57. ISSN 1356-3289. doi:10.1108/13563280510578196

Mohammad, B., Bakar, H. A. \& Rahman, N. A. A. (2007). Relationship between Corporate Identity and Corporate Reputation: A Case of a Malaysian Higher Education Sector. Journal Manajemen Pemasaran, 2(2), 81-89.

Praveena, T. \& Vijaya, K. T. (2015). Corporate Social Responsibility in Education: A Case Study of Hetero Group. 4th Int'l Conference on Research in Humanities, Sociology \& Corporate Social Responsibility (RHSCSR'15) Sept. 25-26, 2015 Penang (Malaysia). http://dx.doi.org/10.15242/ICEHMED915011

Porter, M. E. \& Kramer, M. R. (2006). Strategy and Society: The Link between Competitive Advantage and Corporate Social Responsibility. Harvard Business Review, 1-15. https://hbr.org/2006/12/strategy-andsociety-the-link-between-competitive-advantage-and-corporate-social-responsibility. 
Serap Atakan M. G. \& Eker T. (2007). Corporate Identity of a Socially Responsible University- A Case from the Turkish Higher Education Sector. Journal of Business Ethics, 76(1) 55-68. https://link.springer.com/article/10.1007/s10551-006-9274-3

Smith, A. D. (2007). Making the Case for the Competitive Advantage of Corporate Social Responsibility. Business Strategy Series, 8 (3), 186-195.

Stensaker, B. (2007). The Relationship between Branding and Organizational Change. Higher Education Management and Policy. 19 (1), 13-29.

Yunus, M. \& Weber, K. (2009). Creating a World Without Poverty: Social Business and the Future of Capitalism, New York: Public Affairs. 